\title{
How to succeed in science
}

\section{The Scientific 100: A Ranking of the Most Influential Scientists, Past and Present \\ by John Simmons \\ Citadel: 1996. Pp. 504. \$29.95 \\ W. F. Bynum}

We have the Financial Times 100 top shares and Fortune Magazine's 100 wealthiest people, the 100 best-dressed women and the 100 most eligible bachelors, the 100 best wines and the 100 greatest films. More than a century ago, John Lubbock published The Hundred Best Books (his was not one of them). Why not The Scientific 100?

Even if scientific influence might be more difficult to measure than market value or personal wealth, it ought to be as easy to judge as dress sense or personal desirability. And comparing a naturalist with a theoretical physicist, or a chemist with an anthropologist, should pose no more problems than ranking a claret alongside a pinot noir. There is even a century-old precedent for scientific rankings - James McKeen Cattell based his league table on the number of column inches given to scientists in encyclopaedias.

John Simmons is more egalitarian: his biographical sketches of his ranked 100 best scientists are each roughly the same length, four or five pages. Wilhelm Wundt (number 99) gets about as much space as Isaac Newton (1), and Edward O. Wilson (83) as much as Niels Bohr (3).

Further, Simmons admits that a rough layering rather than a precise ranking might be more appropriate: no one is likely to argue that Ernst Haeckel (90) ought to go above Charles Darwin (4), but they might rank him higher than Wilson, or object to his (or Wilson's) inclusion in the first place. Archimedes is placed last, as a founder of the whole scientific tradition, but he could have gone first; however, the whole list could not be reversed without perversity. Simmons's enterprise is arbitrary, but not completely so. Scientific influence (or worthiness) is difficult to define, but not an illusion; a quartile, if not an absolute rank, makes intuitive sense.

These caveats aside, and with a bottle of first-quartile claret to hand, Simmons's volume becomes enjoyable. It is well written, has a reasonable standard of accuracy and a defensible selection. A disarming appendix discusses "inexcusable omissions, honorable mentions and also-rans". Simmons singles out 50 of these including Aristotle, Hippocrates, Descartes, Robert Boyle, Jons Berzelius and Wolfgang Pauli.

He does not apologize for excluding Leibniz, Thomas Young, Alexander von Humboldt, Peter Medawar or Karl Pearson. Ivan Pavlov probably has a better case for inclusion

than B. F. Skinner (98), Ramón y Cajal than Emil Kraepelin (92), John Enders or Max Theiler than Jonas Salk (91), Howard Florey than Alexander Fleming (97), Georges Cuvier than George Gaylord Simpson (78). Franz Boas (14) and Buffon (23) are flattered by their rankings, and Trofim Lysenko (93) earns his place only as a cautionary tale, here sensibly directed not-against Soviet ideology but American creationist science. With two anthropologists, and Noam Chomsky (71) representinglinguistics, there is a broad definition of 'science.' Inventors and technologists are excluded.

On the assumption that Simmons's ranking is inevitably subjective but more or less sound, what lessons could a young scientist learn who wanted to earn a place in a future 100 ? First, be male, white and middle class. Simmons has identified only three women (Marie Curie, 26, Lynn Margulis, 80, and Gertrude Elion, 85) and no Asians or Africans. Genteel poverty is perfectly acceptable, but only Faraday (11) and Lysenko could boast of real proletarian origins.

Second, a German birth helps. A quarter of his top 100 were born there, although a quarter of those ended up working in the United States. The Nazi-inspired emigration of scientific talent is prominent in Simmons's bio-

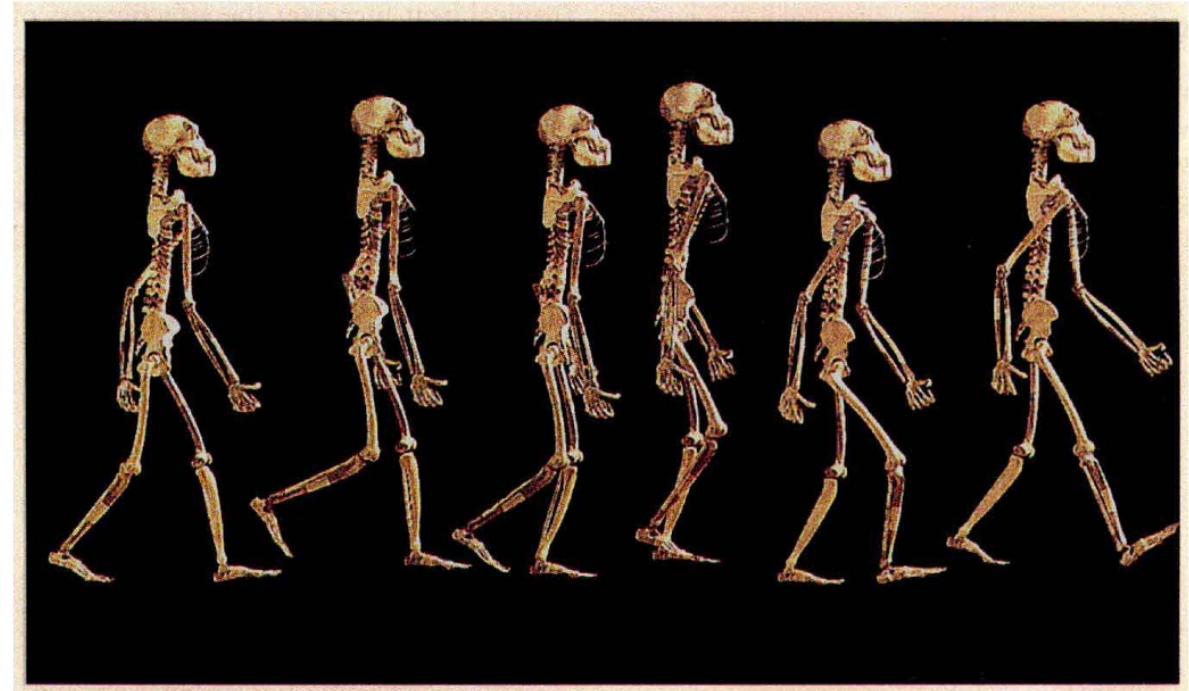

\section{Walk-on part in human evolution}

Australopithecus afarensis lived between 3 and 4 million years ago and is thought to be the earliest known bipedal ancestor of the human species. The first specimen to be found, the partial skeleton known as Lucy, achieved fame and was dubbed "the woman who shook up man's family tree”. Lucy's discoverer, the palaeoanthropologist Donald Johanson, has collaborated with the science writer Blake Edgar to produce From Lucy to Language graphical sketches. The United Kingdom (with 18 scientists listed) ranks second to Germany, with the United States (17) just behind. Of those born in the United States, several had parents who were recent immigrants (GellMann, 45, Glashow, 48, Oppenheimer, 87). The French, more comfortable at home and headed by Pasteur (5), come fourth, with nine listings, followed closely by the Austrians with seven (Freud, 6, tops these). The Austrian émigrés were more selective in their ports of call, including the United Kingdom (Freud), Ireland (Schrödinger, 18) and the United States (Landsteiner, 81, but before the Nazi period).

The current status of American science is highlighted by the fact that all but three of Simmons's living selections reside there (the exceptions are Hawking, 54, Sanger, 72, and Levi-Strauss, 79). Some crumb of American comfort can be derived from the fact that seven of the remaining 11 living scientists were born in the United States, even though the highest-ranked living scientist is British, Francis Crick (33).

A young physicist hoping to reach the top could be advised to head for California (home to most nuclear physicists), whereas life scientists can afford to stay on the East Coast. If a Nobel prize is a priority, avoid evolutionary biology (neither Mayr, 65, Dobzhansky, 67,
(Simon and Schuster/Weidenfeld and Nicolson, \$50, £25), an encyclopaedic overview of human evolution. The book, to be reviewed in a future issue of Nature, includes more than 200 colour plates of the most valuable hominid fossils, artefacts and prehistoric art, many reproduced at actual size. Most of the photos were taken by David Brill. The picture shows a plaster reconstruction of afarensis. 